\title{
MEKANISME PELAYANAN PEMBUATAN IZIN MENDIRIKAN BANGUNAN (IMB)
}

\author{
A.M. Yadisar \\ Fakultas Ilmu Sosial dan Ilmu Politik Universitas Kapuas Sintang \\ Jln. Oevang Oeray Nomor 92 Baning Kota Sintang \\ Email: yadisar75@gmail.com
}

\begin{abstract}
Abstrak: Pelayanan pembuatan Izin Mendirikan Bangunan merupakan salah satu jenis pelayanan yang diselenggarakan Dinas Penanaman Modal dan Pelayanan Terpadu Satu Pintu Kabupaten Sintang terciptanya kualitas pelayanan pembuatan Izin Mendirikan Bangunan tentunya akan menciptakan kepuasan terhadap pengguna layanan. Kualitas mekanisme pelayanan pada akhirnya dapat memberikan beberapa mamfaat diantaranya terjalinnya hubungan yang harmonis antara penyedia layanan dengan masyarakat atau dunia usaha. Kualitas mekanisme pelayanan Izin Mendirikan Bangunan merupakan suatu harapan yang ingin dicapai. Mekanisme pelayanan Izin Mendirikan Bangunan harus mampu memenuhi kualitas layanan yang diharapkan masyarakat dan dunia usaha. Mekanisme pelayanan kepada masyarakat agar tidak mempersulit pelayanan terhadap rakyat, karena tata kelola pemeritahan yang baik (good governance) hanya akan terwujud bila pelayanan itu murah, mudah, dan cepat sesuai dengan tuntutan zaman.
\end{abstract}

Kata Kunci : Mekanisme, Pelayanan, Izin Mendirikan Bangunan

Penyelenggaraan pelayanan publik yang dilaksanakan aparatur pemerintah dalam berbagai sektor pelayanan, terutama yang menyangkut pemenuhan hak-hak sipil pada dasarnya sebagai wujud pertanggungjawaban negara terhadap rakyat. Pelayanan publik yang akhir-akhir ini menjadi issue sentral telah memaksa baik institusi negara maupun masyarakat untuk melakukan regulasi kembali dalam penyelenggaraannya. Meskipun penyediaan pelayanan publik merupakan suatu kewajiban yang harus dilakukan oleh pemerintah sebagai penyelenggara negara. Akan tetapi kewajiban penyediaan pelayanan tersebut masih belum dapat memberikan kepuasan bagi masyarakat penggunanya. Oleh karena itu pelibatan partisipasi masyarakat dalam regulasi pelayanan public mutlak dilakukan, agar dapat diselenggarakan sesuai kesepakatan dan harapan para pihak. Sudah menjadi rahasia umumjika kondisi pelayanan publik masih terus dinilai buruk oleh masyarakat penggunanya. Berbagai keluhan dari masyarakat tentang pelayanan publik yang dikelola pemerintah masih sering terdengar.

Sesungguhnya pemerintah telah melakukan upaya-upaya perbaikan pelayanan publik melalui berbagai kebijakan dibidang pelayanan publik, namun kualitas pelayanan publik masih terus dinilai buruk oleh masyarakat. Menghadapi situasi tersebut, nampaknya upaya perbaikan dan regulasi kebjikan penyelenggaraan layanan publik masih harus terus dilakukan terutama pada upaya-upaya perbaikan yang bersifat implementatif. Menjawab tantangan tersebut, maka berbagai upaya perbaikan regulasi kebijakan penyelenggaraan layanan publik mutlak dilaksanakan, untuk dapat membantu instansi pemerintah penyelenggara pelayanan publik dalam memperbaiki kinerja pelayanan. Beberapa manfaat dari regulasi kebijakan pelayanan antara lain adalah untuk memberikan kepastian dan jaminan kepada masyarakat bahwa mereka akan mendapatkan pelayanan yang berkualitas dan dapat dipertanggung jawabkan.

Dinas Penanaman Modal dan Pelayanan Terpadu Satu Pintu salah satu tugasnya melaksanakan koordinasi dan penyelenggaraan serta pelayanan administrasi di bidang perizinan dengan prinsip koordinasi, integrasi, singkronisasi, dan simplifikasi. Dari semua jenis pelayanan perizinan, pelayanan perizinan khususnya Izin mendirikan bangunan merupakan salah satu layanan dengan tingkat permohonan tertinggi. Namun sayangnya penyelenggaraan pelayanan publik yang merupakan gambaran nyata kinerja pemerintah dalam memberikan layanan kepada masyarakat belum berjalan secara optimal, terutama menyangkut mekanisme dan tata cara pelayanan yang dirasakan masih panjang.

Merujuk pada ketetapan MPR RI No. XI/ MPR/1988 tentang penyelenggaraan Negara yang bersih dan bebas dari korupsi, kolusi dan nepotisme $(\mathrm{KKN})$. Mengamanatkan agar aparatur Negara mampu menjalankan tugas dan fungsinya secara propesional, produktif, transparan, dan bebas dari KKN. Perwujudan nyata dari sikap aparatur negara cercermin dari penyelenggaraan pelayanan publik. Hakikat pelayanan publik adalah memberikan pelayanan prima kepada masyarakat yang merupakan perwujudan kewajiban aparatur pemerintahan sebagai abdi masyarakat. Karena itu pengembangan kinerja pelayanan publik senantiasa menyangkut tiga unsur pokok yakni: kelembagaan penyelenggaraan, proses pelayanannya, serta sumber daya manusia pemberi pelayanan. 
Pelaksanaan reformasi administrasi pelayanan publik memang dipicu oleh semangat demokrasi yang muncul dalam sebuah negara, tuntutan demokrasi pula yang mendorong pemerintah untuk melakukan perubahan terhadap administrasi pelayanan publiknya. Sopian Efendi (1999) mengatakan bahwa telah terjadi perubahan reformasi dalam sistem pemerintahan, juga dilakukan reformasi terhadap administrasi pelayanan publik yang bertujuan untuk meningkatkan kinerja (performance) dan memaksimalkan sistem administrasi pemerintahan.

Penyelenggaraan pelayanan publik oleh lembaga pemerintah kepada masyarakat warga negara dapat kita kaji dengan mengikuti alur perkembangannya. Barzelay dan Armajani, sebagaimana dikutip oleh Yeremias T Keban (1992), menyampaikan adanya pergeseran dari paradigm birokratik, menuju ke paradigm "post bureaucratic paradigm. Sementara itu David Osbonrne dan Peter Plastrik, menyampaikan pemikirannya tentang perkembangan paradigm administrasi negara, yang sangat reformatif yaitu "Reinventing G overnment". Di dalam paradigma ini pemerintah pada saat sekarang harus lebih bersifat :1.Catalytic, 2.Community owned, 3.Competitive, 4. Mission driven, 5.Result oriented, 6.Customer driven,7. Enterprising, 8. Anticipatory, 9. Decentralized, 10. Market oriented.

Pemerintah sebagai penyelenggaran pelayanan publik diharuskan memiliki fungsi katalitis, mampu untuk memberdayakan masyarakat, melakukan upaya-upaya untuk mendorong semangat kompetisi, selalu berorientasi kepada misi, lebih mengutamakan dan mengutamakan hasil daripada cara atau proses, kepentingan masyarakat sebagai acuan utama, berjiwa wirausaha, dan selalu bersikap antisipatif atau berupaya mencegah timbulnya masalah, bersifat desentralistis dan berorientasi pada pasar. Oleh karena itu misalkan terjadi suatu perselisihan, sengketa dan atau pengaduan, maka prosep pengelolaannya diselaraskan dengan asas-asas tersebut.

Terciptanya kualitas pelayanan tentunya akan menciptakan kepuasan terhadap pengguna layanan. Kualitas layanan ini pada akhirnya dapat memberikan beberapa mampaat, diantaranya terjalinnya hubungan yang harmonis antara penyedia jasa dengan masyarakat (public), dan membentuk suatu rekomendasi dari mulut ke mulut (word of mounth) yang menguntungkan bagi penyedia jasa tersebut. Untuk itu kualitas pelayanan di sisi penyelenggara pelayanan merupakan sasaran yang ingin dicapai, sedangkan dari masyarakat, kualitas pelayanan merupakan suatu harapan yang ingin dicapai.
Dalam hal ini pelayanan yang diharapkan publik adalah pelayanan yang berkualitas. Kualitas pada dasarnya terkait dengan pelayanan yang baik, yaitu suatu sikap atau cara pegawai dalam melayani pelanggan atau masyarakat secara memuaskan. Sebagaimana dikemukakan Trigono (1997: 76-78) bahwa pelayanan yang terbaik yaitu "melayani setiap saat, secara tepat dan memuaskan, berlaku sopan, ramah dan menolong serta professional dan mampu". Untuk itu diusahakan adanya pelayanan prima.

Menurut Sutopo dan Suryanto (2003:10) bahwa "pelayanan prima adalah terjemahan dari istilah excellent service yang secara harfiah berarti pelayanan yang sangat baik atau pelayanan yang terbaik". Disebut sangat baik atau terbaik karena sesuai dengan standar pelayanan yang berlaku atau dimiliki oleh intansi yang memberikan pelayanan. Tujuan dari pelayanan prima adalah memberikan pelayanan yang dapat memenuhi dan memuaskan pelanggan atau masyarakat serta memberikan fokus pelayanan kepada pelanggan. Barkualitas mempunyai arti memuaskan kepada yang dilayani, baik internal maupun ekternal dalam arti optimal pemenuhan atas tuntutan pelanggan atau masyarakat. Gaspersz (dalam Lukman, 2000) menyatakan bahwa kualitas pelayanan adalah segala sesuatu yang mampu memenuhi keinginan atau kebutuhan pelanggan (meeting the needs of customers)

Pelayanan pemerintah adalah suatu keinginan yang merupakan perwujudan dari salah satu fungsi pemerintah itu sendiri, yang bertujuan untuk mensejahterakan masyarakat. Sebagaimana pendapat Yudoyono (dalam Ndraha, 2003) mengatakan bahwa jajaran pemerintah terutama yang bertugas di garis terdepan bidang pelayanan masyarakat agar tidak mempersulit pelayanan terhadap rakyat, karena pemerintahan yang baik (good governance) hanya akan terwujud bila pelayanan itu murah, mudah dan cepat. Selanjutnya Rasyid (1997) mengatakan bahwa fungsi utama pemerintah adalah pelayanan kepada masyarakat, yang bertujuan menciptakan kondisi yang menjamin warga masyarakat melaksanakan kehidupan mereka secara wajar.

Kualitas Pelayanan yang diberikan oleh pemerintah dapat diukur setelah masyarakat menerima dan merasakan layanan serta membandingkan dengan harapan sebelumnya. Kulaitas pelayanan merupakan salah satu aspek yang mendapat perhatian dari pemerintah, guna memberikan kepuasan kepada rakyat. Apabila layanan sipil bila dilihat dari keberadaannya merupakan hak hak dasar dari warga negara dan hanya pemerintah yang memproduksi dan mendistribusikannya. Ndraha (1997) mengemukakan bahwa setiap warga negara berhak 
atas layanan sipil tanpa dibebani dan tanpa dikaitkan dengan suatu finansial apapun. Karena itu , layanan sipil disebut no rice, layanan sipil seratus persen dibayar dari pendapatan negara.

Secara spesipik aspek-aspek yang harus diperhatikan dalam penyelenggaraan pelayanan yang berkualitas menurut Ndraha (1997) adalah jasa layanan atau layanan sipil dipandang sebagai deviden yang wajib didistribusikan kepada rakyat oleh pemerintah dengan semakin baik, semakin tepat waktu, semakin mudah diperoleh dan semakin adil. Tekanan kepada aspek kecepatan, ketepatan, kemudahan dan keadilan dalam layanan publik tersebut berkaitan dengan sifat monopoli pelayanan publik dimana masyarakat tidak memiliki pilihan untuk mengharapkan layanan yang sama pada intstitusi lain diluar pemerintah.

\section{METODE PENELITIAN}

Penelitian terhadap Mekanisme Pelayanan Pembuatan Izin Mendirikan Bangunan oleh Dinas Penanaman Modal dan Pelayanan Terpadu Satu Pintu Kabupaten Sintang dengan pendekatan penelitian deskriptif kualitatif yang bersifat menerangkan fenomena yang diteliti. Data dalam penelitian ini terdiri : 1) data primer, yaitu data yang diperoleh dari hasil wawancara dengan informan. 2) data sekunder, yaitu data yang diperoleh dari dokumen, laporan dan buku-buku yang mendukung data. Sementara instrumen penelitian adalah peneliti sendiri, dengan dilengkapi panduan wawancara kepada key person untuk memperoleh data yang diperlukan.

Informan yang dipilih dalam penelitian ini adalah a) Pejabat dari Dinas Penanaman Modal dan Pelayanan Terpadu Satu Pintu Kabupaten Sintang, b) Pegawai dari Dinas Penanaman Modal dan Pelayanan Terpadu Satu Pintu Kabupaten Sintang, c) Masyarakat pengguna pelayanan yang ditemui secara accidental di lapangan. Pengumpulan data yang dipergunakan dalam rangka penelitian adalah sebagai berikut : 1) Wawancara mendalam, yaitu melakukan wawancara kepada informan yang terlibat langsung dan mengetahui pelaksanaan kebijakan pembuatan Izin Mendirikan Bangunan tersebut, 2) Pengamatan langsung, yaitu peneliti terjun langsung ke lapangan dan mengamati secara langsung pelaksanaan kebijakan pembuatan Izin Mendirikan Bangunan dimaksud.

Analisis data yang digunakan adalah analisis taksonomis yaitu bentuk analisis yang lebih rinci dan mendalam dalam membahas suatu tema atau pokok permasalahan. Dimana domaian atau bidang yang ditonjolkan perlu dilacak secara mendalam dan terinci struktur internalnya.

\section{HASIL DAN PEMBAHASAN Mekanisme Pelayanan}

Pelayanan yang diberikan kepada masyarakat oleh pemerintah melalui aparat pemerintah, walaupun tidak bertujuan untuk mencari keuantungan namun harus tetap mengutamakan kualitas pelayanan yang sesuai dengan tuntutan. Setiap pelayanan akan menghasilkan beragam penilaian yang datang dari pihak yang dilayani atau pelanggan. Pelayanan yang baik tentunya akan memberikan peneilaian yang baik pula dari para pelanggan, tetapi apabila pelayanan yang diberikan tidak memberikan kepuasan, maka akan menimbulkan kekecewaan pelanggan dan bisa mempengaruhi citra intansi yang memberikan pelayanan.

Untuk pelayanan yang diberikan oleh intansi pemerintah harus mengikuti prosedur yang berlaku. Adapun prosedur pelayanan menurut KEPMEN PAN No. 26 Tahun 2004 Tentang Petunjuk Teknis Transparansi dan Akuntabilitas dalam Penyelenggaraan Pelayanan Publik, menjelaskan bahwa Prosedur Pelayanan adalah rangkaian proses atau tata kerja yang berkaitan satu sama lain, sehingga menunjukan adanya tahapan secara jelas dan pasti serta cara yang harus ditempuh dalam rangka menyelesaikan suatu pelayanan. Suatu prosedur palayananan menunjukan adanya langkah-langkah atau caracara sebagai pedoman yang harus dilaksanakan pada setiap tahapan dalam serangkaian proses penyelesaian pelayanan public.

Diterbitkannya Peraturan Pemerintah Nomor 41 Tahun 2007 tentang Organisasi Perangkat Daerah, Pemerintah Daerah Kabupaten Sintang telah menerbitkan Peraturan Daerah yang berhubungan dengan pembentukan Susunan Organisasi Perangkat Daerah, yaitu Peraturan Daerah Kabupaten Sintang Nomor 7 Tahun 2016 Tentang Susunan Organisasi Perangkat Daerah Kabupaten Sintang, Peraturan Bupati Sintang Nomor 122 Tahun 2016, dimana tugas pelayanan perizinan dilaksanakan oleh Dinas Penanaman Modal dan Pelayanan Terpadu Satu Pintu. Berdasarkan Peraturan Daerah tersebut, susunan organisasi dan tata kerja Dinas Penanaman Modal dan Pelayanan Terpadu Satu Pintu (DPMPTSP) Kabupaten Sintang terdiri dari: Kepala Dinas; Sekretaris Dinas; Kabid Perencanaan, Pengendalian, dan Pengawasan Penanaman Modal; Kabid Promosi, Data dan Sistem Informasi Penanaman Modal; Kabid Pengaduan, Kebijakan, dan Pelaporan layanan; Kabid Penyelenggaraan Perizinan dan Non Perizinan; Kasubbag Keuangan dan Program; Kasubbag Aparatur dan Umum; Kasi Pengendalian dan Pengawasan Penanaman Modal; Kasi Perencanaan dan Potensi Penanaman Modal; Kasi Promosi dan Fasilitasi Penanaman 
Modal; Kasi Sistem Informasi dan Pengolahan Data Penanaman Modal; Kasi Kebijakan, Pelaporan dan Peningkatan Layanan; Kasi Pengaduan, Informasi dan Penyuluhan Layanan; Kasi Pelayanan Perizinan dan Nonperizinan A/I; Kasi Pelayanan Perizinan dan Nonperizinan A/II; dan Kelompok Jabatan Fungsional.

Dinas Penanaman Modal dan Pelayanan Terpadu Satu Pintu Kabupaten Sintang menyelenggarakan dua jenis pelayanan yaitu pelayanan perizinan dan pelayanan non perizinan. Jenis-jenis pelayanan perizinan terdiri dari: Izin Mendirikan Bangunan (IMB) rumah tempat tinggal, Izin usaha kontruksi, Izin industri, Izin perluasan industri, Izin ganguan (HO), Izin relame, Izin bengkel, Izin kursus, Surat izin tempat usaha (SITU) dan Surat izin perdagangan (SIUP). Sedangkan untuk jenis pelayanan non perizinan terdiri dari: Pelayanan Informasi dan pengaduan, tanda daftar industri (TDI), Tanda daftar gudang (TDG), Tanda daftar perusahaan (TDP) dan Tanda daftar ulang (TDU).

Berdasarkan hasil penelitian terjadinya peningkatan Nilai hasil Survey Indeks Kepuasan Masyarakat (IKM) terhadap pelayanan Publik di Dinas Penanaman Modal dan Pelayanan Terpadu Satu Puntu Kabupaten Sintang selama 3 (tiga) tahun terakhir yaitu: Tahun 2018 sebesar 86,26; Tahun 2019 sebesar 87; dan Tahun 2020 sebesar 89.

Proses pelayanan yang baik tidak terlepas dari mekanisme dalam memberikan pelayanan. Hasil penelitian menunjukan bahwa mekanisme pelayanan izin reklame terdiri dari beberapa tahapan yaitu: 1) Pengajuan berkas permohonan di loket pelayanan Dinas Penanaman Modal dan Pelayanan Terpadu Satu Pintu Kabupaten Sintang; 2) Pemeriksaan berkas oleh Petugas; 3) Petugas turun ke lapangan untuk melakukan pemeriksaan lapangan; 4) Proses pembuatan Surat Keputusan Perizinan; dan 5) Penyerahan Perizinan. Proses penyelesaian perizinan paling lama 14 hari kerja sejak pengajuan berkas permohonan dan ababila proses dilakukan secara eloktronik dengan menggunakan system OSS dan jika tidak mengalami kendala teknis serta persyaratan dokumen telah lengkap dan benar penyelesaian dokumen dapat dilakukan 1 hari kerja.

Izin mendirikan bangunan terkelompokan dalam beberapa jenis yaitu 1) Izin Mendirikan Bangunan Pendahuluan untuk Bangunan Sederhana; 2) Izin Mendirikan Bangunan Pendahuluan Gedung Tidak Sederhana Bukan untuk Kepentingan Umum; 3) Izin Mendirikan Bangunan Pendahuluan Gedung Tidak Sederhana untuk Kepentingan Umum dan Bangunan Khusus; 4) Izin Mendirikan Bangunan Penerbitan; 5) Izin Mendirikan Bangunan Balik Nama untuk
Bangunan yang tidak Mengalami Perubahan: 6) Izin Mendirikan Bangunan Final. Masing-masing jenis permohonan Izin Mendirikan Bangunan memiliki persyaratan dokumen yang berbeda.

Pengajuan berkas permohonan kepada petugas di loket pelayanan harus melampirkan syarat-syarat untuk pembuatan Izin Mendirikan Bangunan Pendahuluan untuk Bangunan Sederhana yaitu: 1) Mengisi formulir yang disediakan; 2) Foto Copy Kartu Tanda Penduduk; 3) Foto copy Surat Tanda Hak Tanah; 4) Tanda Lunas PBB Tahun yang sedang berjalan; 5) Keterangan Rencana Kabupaten (KRK)/Advice Planing; 6) Surat Pernyataan Mengikuti Kentetuan dalam KRK; 7) Sket Lokasi beserta Rencana Bangunan lengkap (Rencana Arsitektur) yang disyahkan Dinas, yang memuat: Gambar Situasi/ Rencana Tapak, Gambar Denah, Gambar Tapak, Gambar Potongan dan gambar Detail arsitektur.; 8) Surat Pernyataan bahwa Tanah tidak dalam Sengketa;

Biaya tarif restribusi Izin Mendirikan Bangunan sangat berpariatif tergantung dari jenis permohonan Izin Mendirikan bangunan. Berdasarkan Peraturan Daerah Kabupaten Sintang Nomor 6 Tahun 2012 Tentang Restribusi Perizinan Tertentu, mengkasifikasi penghitungan restribusi Izin Mendirukan bangunan yaitu: 1) Restibusi Pembangunan baru: L x lt x 1,00 x HSbg; 2 . Restribusi Rehabilitasi/Renovasi Bangunan: L x lt x Tk x Hsbg; 3) Rehabilitasi Prasarana Bangunan: V x 1 x Tk x HSpbg; 4) Restribusi Prasarana Bangunan: V x 1 x Tk x HSpbg.

Standar dalam memberikan pelayanan yaitu peraturan Bupati Nomor 12 Tahun 2010 tentang Standar Operasional Prosedur Pelayanan Perizinan dan Non Perizinan. Standar pelayanan ini masyarakat dapat mengetahui apa saja syaratsyarat dan prosedur dari tiap jenis pelayanan. Dilihat dari segi ketepatan waktu dalam memberikan izin belum bisa dikatakan baik, hal ini dikarenakan kelengkapan persyaratan administrasi, perlu pengecekan kelapaangan, kepala kantor tidak berada ditempat.

Aspek ketepatan ini berkaitan dengan ketepatan dalam prosedur perizinan, ketepatan pemberian izin kepada orang yang sesuai dengan persyaratan dan ketepatan lokasi dalam perizinan. Ketepatan prosedur berkaitan erat dengan syaratsyarat yang harus dipenuhi oleh pemohon perizinan baik menyangkut syarat administrasi maupun persyaratan fisik (kelayakan tempat). Kemudian berkaitan dengan ketepatan pemberian kepada orang yang sesuai dengan persyaratan berarti izin itu diberikan kepada pemohon yang benar-benar memiliki status kependudukan yang jelas serta adanya sarana pendukung, baik berupa gedung, lokasi, dan sarana transportasi. Sedangkan 
berkaitan dengan ketepatan lokasi dimaksud bahwa lokasi yang digunakan tidak dijalur hijau, serta tidak bermasalah atau dalam sengketa.

Kualitas pelayanan masih belum maksimal dilihat dari ketapatan pelayanan, karena masih terdapatnya banyak kendada-kendala dilihat dari mekanisme kinerja pegawai, namun diharapkan kedepan lebih baik terutama yang bersifat administratif maupun yang bersifat teknis pelayanan. Ketepatan waktu merupakan salah satu indikator kualitas pelayanan publik yang diberikan penyelenggara pelayanan publik. Semakin tepat waktu penyelesaian permohonan izin maka semakin berkualitas pelayanan publik yang diberikan. Namun sebaliknya ababila semakin tidak tepat waktu penyelesaian permohonan izin dilakukan maka semakin rendah kualitas pelayanan. Untuk itu harus adanya komitmen dari penyelenggara pelayanan public untuk menciptakan kinerja yang tepat waktu dan tepat sasaran.

Ketepatan waktu pelayanan dapat tercipta apabila didukung oleh sumber daya manusia yang memadai baik dari segi kuantitas dan maupun kualitas. Adanya sumber daya manusia yang memiliki etos kerja serta motipasi yang tinggi dalam pelayanan akan menciptakan pelayanan yang tepat. Disamping itu pelayanan bisa tepat apabila didukung oleh sarana dan prasarana kantor yang memadai.

Pelayanan yang cepat merupakan salah satu indicator tingkat kualitas pelayanan. Pelayanan perizinan merupakan salah satu representasi dari suatu kualitas jasa layanan. Gap (jurang) yang terjadi antara terpenuhinya atau tidak terpenuhinya layanan yang dibutuhkan oleh masyarakat (pemohon izin) mencerminkan realitas kualitas jasa layanan di masyarakat. Arti kualitas jasa yang diberikan dapat tergambar dengan jelas, tergantung pada pelayanan yang diberikan oleh penyenggara pelayanan. Publik akan memberikan penilaian yang positif apabila pelayanan yang diberikan secara cepat dan tepat. Namun sebaliknya, apabila pelayanan yang diberikan kurang tepat dan lambat maka public akan memberikan penilaian yang negatif.

Terobosan untuk mempercepat pelayanan perizinan sehingga penyelesaian pelayanan perizinan hanya perlu waktu 1 (satu) hari atau paling lama 14 (empat belas) hari. Perlu adanya peninjauan kembali dan penelaahan proses dan prosedur yang bisa menghambat atau mempersulit kecepatan penyelesaian pelayanan perizinan. Salah satu kendala adalah adanya otoritas verifikasi berkas, untuk itu perlu adanya pelimpahan wewenang kepada pejabat yang ada dibawahnya, sehingga apabila pejabat tidak ada di tempat maka dapat didelegasikan kepada pejabat lain, dengan demikian pelayanan tidak harus menunggu karena pejabat yang berwenang tidak ditempat.
Kepuasan masyarakat terhadap pelayanan publik dapat digambarkan dari penerimaan masyarakat pada layanan yang diberikan. Apabila masyarakat merasa kurang puas terhadap pelayanan perizinan maka kemungkinan masyarakat akan mengeluh. Untuk itu sudah seharusnya bila Dinas Penanaman Modal dan Pelayanan Terpadu Satu Pintu memikirkan cara atau strategi untuk memberikan kemudahan kepada pemohon Izin tanpa harus melanggar prosedur yang telah ditetapkan, sehingga pelayanan izin reklame akan lebih mudah, cepat, efektif dan efisien.

Aspek yang perlu diperhatikan dari dimensi keadilan, pelayanan Izin Mendirikan Bangunan harus berada pada rel kemanusiaan yang diharapkan berwajah humanis sekaligus akuntabel kepada masyarakat. Pelayanan yang adil adalah pelayanan yang tampa diskriminasi, pelayanan yang tanpa membedakan orang, pelayanan tanpa pandang bulu. Pelayanan yang adil adalah pelayanan yang memerlukan setiap pemohon perizinan sama dengan pemohon perizinan yang lain. Dengan menggunan prinsip pelayanan yang berkeadilan maka setiap pemohon diberikan hak, kewajiban, dan perlakuan yang sama sehingga tidak menimbulkan kecemburuan pelayanan.

Keadilan dalam pelayanan merupakan bentuk komitmen pegawai dalam memberikan pelayanan Izin Mendirikan Bangunan yang setara dan berkeadilan. Dengan adanya keadilan dalam pelayanan maka masyarakat tidak merasa dibedabedakan ataupun dianak tirikan. Pelayanan yang diskriminatif akan menimbulkan komflik baik antara pegawai dengan masyarakat (pemohon izin) maupun antara pemohon izin itu sendiri. Pelayanan Izin Mendirikan Bangunan yang menjunjung keadilan merupakan bentuk penghargaan terhadap masyarakat yang berhak mendapat perlakuan yang sama dalam penyelenggaraan pelayanan.

Unsur-unsur pokok yang terkandung dalam pelayanan yang unggul (service excellence) yaitu ketepatan, kecepatan, kemudahan dan keadilan merupakan satu kesatuan yang terintegrasi dalam mewujudkan kualitas pelayanan. Kualitas pelayanan yang baik akan dapat memberikan kepuasan kepada masyarakat yang pada akhirnya akan memberikan kepercayaan kepada pemerintah terhadap penyelenggaraan pelayanan.

Penyelenggaraan pelayanan publik yang berkualitas merupakan kewajiban yang harus dilakukan oleh setiap penyelenggara negara. Bahkan dikatakan bahwa salah satu tolok ukur keberhasilan penyelenggaraan negara dapat dilihat dari kualitas pelayanan publik yang disediakan. Oleh karena itu upaya pemerintah Kabupaten Sintang melalui Dinas Penanaman Modal dan Pelayanan Terpadu Satu Pintu Kabupaten Sintang untuk menyelenggaraakan pelayanan pembuatan Izin 
Mendirikan Bangunan yang berkualitas dan berkeadilan terus menerus dilakukan melalui berbagai kebijakan pengaturan dibidang pelayanan publik. Paradigma pelayanan yang dikembangkan pun bergeser dari yang berorientasi pada pelayanan yang keadilan distributif menuju pada pelayanan yang keadilan yang komotatif, pelayanan dilaksanakan lebih demokratis dan berorientasi pada kepentingan para pihak yaitu penyelenggara pelayanan dan pengguna pelayanan pembuatan Izin Mendirikan Bangunan.

Kebijakan, dalam hal ini kebijakan yang mengatur kualitas pelayanan pembuatan Izin Mendirikan Bangunan, dikonsepkan sebagai sebuah "konstruksi" yang batasan definitifnya terikat pada dimensi dan waktu takala subjeksubjek berinteraksi secara komunikatif untuk menghasilkan produk pemikiran yang sama. Artinya, keijakan dalam konteks studi pelayanan publik tidak akan difahami sebagai entitas normatif yang objektif semata, tetapi dipahami sebagai dependen variable dari suatu proses sosial politik yang melibatkan sejumlah actor individu yang berpartisipasi dalam suatu proses.

Dengan demikian, proses konstruksinya, dengan demikian, juga tidak dipahami sekadar tehnik konstruksi kebijakan sebagai prosedur standar, tetapi dipahami sebagai totalitas proses yang berada dalam keadaan saling berkait dengan variable sosial, kultur dan politik. Konstruksi kebijakan kulaitas pelayanan publik dipahami sebagai produk politik yang karakternya antara lain ditentukan oleh dinamika sosial yang berkaitan dengan administrasi publik dan lebih khusus lagi berkenaan dengan kebijakan pelayanan publik.

Oleh karena itu didalam mengkonstruksi kebijakan pelayanan publik salah satunya pelayanan pembuatan Izin Bangunan, maka konstruksi kebijakan penyelenggaraan pelayanan publik harus lebih memenuhi harapan masyarakat. yang memungkinkan terealisasinya Standar Pelayanan, dalam kerangka penyelenggaraan pelayanan pembuatan Izin Mendirikan Bangunan, yang lebih responsif dan partisipatif dan yang secara khusus lebih bersesuai dengan kondisi yang berkembang dalam masyarakat Kabupaten Sintang.

Diketahui lewat penelitian ini bahwa perubahan-perubahan sosial-kultural dan politik telah terjadi di daerah-daerah, yang berdampak pada terjadinya pergeseran yang menuju ke terjadinya berbagai ragam respons, yang dapat diduga akan lebih memenuhi tututan dan kebutuhan masyarakat. Pergeseran ini berseiring dengan pergeseran paradigma yang mengarah ke paradigma baru yang disebut The New Public Service Paradigm, yang mensyaratkan terpenuhinya kriteria partisipasi, keadilan sosial, transparansi, kepastian dan keterjangkauan bagi dan oleh masyarakat yang berhak atas pelayanan publik. Dari penelitian yang dilakukan diwilayah penelitian diperoleh fakta regulasi dan Standar Pelayanan Publik yang bervariasi sehubungan dengan kondisi sosial, budaya dan kebutuhan masyarakat.

Pemberian ruang partisipasi masyarakat dalam pengaturan penyelenggaraan pelayanan pembuatan Izin Mendirikan Bangunan dimaksudkan untuk mengakomodasi tuntutan demokrasi yang berkembang dalam masyarakat. Dengan diakomodasinya kepentingan dan kebutuhan masyarakat diharapkan akan terbangun komitmen bersama dalam kegiatan penyelenggaraan pelayanan dalam masyarakat. Komitmen bersama dapat dibina dengan mengesampingkan kepentingan dan ego kedinasan dalam masyarakat. Pengaturan penyelenggaraan pelayanan pembuatan Izin Mendirikan Bangunan yang dibangun dengan komitmen bersama akan menghasilkan kebijakan dan aturan yang mencerminkan moralitas kerja-sama. Perilaku penyelenggara pelayanan dan masyarakat pengguna pelayanan akan tunduk pada prinsipprinsip dan kebijakan yang telah disepakati.

Sementara itu, mekanisme pengaturan dan penyelenggaraan pelayanan pembuatan Izin Mendirikan Bangunan pun dapat diharapkan kalau akan berjalan dalam suatu situasi saling kontrol antara para penyelenggara dan warga masyarakat pengguna jasa pelayanan. Melalui mekanisme ini akan tercipta pelayanan yang berkeadilan serta meningkatkan posisi warga, tidak saja sebagai pengguna pelayanan saja tetapi juga sebagai pihak yang akan lebih berposisi tawar (bargain) yang lebih baik untuk mendapatkan jasa pelayanan yang lebih baik. Tanggung jawab bersama yang dikembangkan melalui ruang partisipasi masyarakat dengan model tersebut di atas juga dapat diharapkan akan merangsang penyelenggara pelayanan untuk mengembangkan dan memperluas kompetensi aparaturnya agar senantiasa dapat melaksanakan tugas pelayanan dengan lebih baik.

Model penyedian ruang partisipasi masyarakat dalam pengaturan dan penyelenggaraan pelayanan, diharapkan akan mampu memberi pembelajaran kepada masyarakat untuk lebih bertanggungjawab dalam proses demokrasi yang sedang berjalan. Model partisipasi dalam penyelenggaraan pelayanan yang mengedepankan tanggungjawab bersama, para pihak diharapkan senantiasa mengembangkan pencarian alternatif secara positif berkait sistem pengaturan, system penyelenggaraan, dan kewajiban berswasembada untuk tidak bergantung kepada pihak luar. Pemberian insentif kepada penyelenggara dan pengguna pelayanan dapat 
dikembangkan melalui forum pelibatan para pihak dalam ruang partisipasi masyarakat

Regulasi penyelenggaraan pelayanan publik yang melibatkan para pihak dengan tujuan terbinanya komitmen bersama dalam ruang partisipasi masyarakat, ialah antara penyelenggara pelayanan dan warga masyarakat, akan mengantar para pihak ke dalam proses pengaturan penyelenggaraan pelayanan yang lebih responsif. Sebuah regulasi yang dapat memenuhi tuntutan agar aturan hukum terkonstruksi sebaga produk proses yang lebih responsif pada kebutuhan sosial yang terasa mendesak, dan bersamaan dengan itu juga tetap mempertahankan kontruksi-konstruksi normatif.

Berdasarkan hasil penelitian dan pemikiran teoretisisasinya, menyarankan perlunya mengatur pelayanan pembuatan Izin Mendirikan Bangunan dengan suatu regulasi yang diundangkan dalam bentuk suatu Peraturan Daerah Kabupaten Sintang yang tanggap pada norma-norma lokal yang terpilih sebagaimana yang berlaku dan berkembang dalam masyarakat. Peraturan Daerah yang menetapkan Standar Pelayanan Pembuatan Izin Mendirikan Bangunan yang tanggap pada tuntutan daerah seperti itu boleh diharapkan akan mampu menyelesaikan berbagai problem praktis yang mengatur prosedur, penetapan biaya, waktu dan mekanisme pengaduan dan penetapan fasilitas pelayanan yang nantinya akan melahirkan kualitas pelayanan.

Standar Pelayanan Pembuatan Izin Mendirikan Bangunan yang disusun secara konstruktif dan lebih responsif, dengan mengundang partisipasi masyarakat seperti itu, dipandang perlu untuk diproses lebih lanjut, sehingga tidak lagi berwujud penetapan normatif yang sentral, melainkan sudah berupa kontrak pelayanan antara pemerintah daerah dan masyarakat setempat. Standar Pelayanan untuk kepentingan publik seperti itu amat mendesak untuk segera diwacanakan.

\section{KESIMPULAN DAN SARAN}

Pelaksanaan Mekanisme Pelayanan Pembuatan Izin Mendirikan Bangunan yang dilakukan Dinas Penanaman Modal Palayanan Terpadu Satu Pintu Kabupaten Sintang sudah sesuai dan mengacu kepada Paraturan Bupati Nomor 12 tahun 2010 tentang Standar Operasional Prosedur Pelayanan Perizinan dan Non Perizinan. Dilihat dari dimensi ketepatan prosedur, ketepatan dan kemudahan dalam pelayanan Izin Mendirikan sudah berjalan sesuai dengan ketentuan, walaupun dari sisi ekspektasi harapan masyarakat dan dunia usaha masih belum sesuai dengan harapan. Dalam mekanisme pelayanan Izin Mendirikan Bangunan faktor kemampuan dan keterampilan pegawai/ aparatur sudah sangat mendukung, demikian pula dengan ketersediaan sarana prasarana pelayanan Izin Mendirikan Bangunan sudah memadai.

Didalam merumuskan kebijakan kualitas pelayanan pembuatan Izin Mendirikan Bangunan, maka konstruksi perumusan kebijakan penyelenggaraan pelayanan pembuatan Izin Mendirikan Bangunan harus lebih memenuhi harapan masyarakat. yang memungkinkan terealisasinya Standar Pelayanan Pembuatan Izin Mendirikan Bangunan, dalam kerangka penyelenggaraan kebijakan pelayanan kepada masyarakat, yang lebih responsif dan partisipatif dan yang secara khusus lebih bersesuai dengan kondisi yang berkembang dalam masyarakat di Kabupaten Sintang.

Diharapkan dalam memenuhi kecepatan dalam pembuatan Izin Mendirikan Bangunan, perlu adanya penyederhanaan persyaratan administrasi. Peninjauan kembali terhadap Mekanisme dan persyaratan administrasi dalam pengurusan perizinan memiliki urgensi yang vital dalam pemberian perizinan serta pengembangan perijinan berbasis system online dan parallel sehingga akan efektif dan efisien. Transparansi dan akutabilitas dalam menerapkan prosedur dan persyaratan pelayanan perlu terus dikembangkan. Perlunya mengkonstruksi perumusan kebijakan pelayanan pembuatan Izin Mendirikan Bangunan dengan suatu regulasi yang tanggap pada norma-norma lokal yang terpilih sebagaimana yang berlaku dan berkembang dalam masyarakat setempat dan tuntutan dunia usaha. Model penetapan kebijakan pelayanan pembuatan Izin Mendirikan Bangunan yang tanggap pada tuntutan daerah seperti itu boleh diharapkan akan mampu menyelesaikan berbagai problem praktis yang mengatur mekanisme, penetapan biaya,waktu dan mekanisme pengaduan dan penetapan fasilitas pelayanan. Perlu dilakukan sosialisasi kepada masyarakat secara berkesinambungan tentang tata cara pembuatan Izin Mendirikan Bangunan, baik mengenai mekanisme, biaya, waktu, dan kegunaannya.

\section{DAFTAR PUSTAKA}

Dwiyanto, Agus et al. 2008. Mewujudkan Good Governance Melalui Pelayanan Publik, Cetakan Ketiga. Yogyakarta: Gadjah Mada University Press.

Irawan, Hamdi. 2002. 10 Prinsip Kepuasan Pelanggan. Jakarta: PT Gramedia.

Kencana, Syafie, Inu, et. al. 1999. Ilmu Administrasi Publik. Cetakan Pertama. Jakarta: Rineka Cipta. 
Kotler, P. 1997. Marketing Management: Analisys, Planning, Implementation and Control.. 9 th edition. New York : Addims-Wesley Oublishing Company

Moeninr, H.A.S. 2002. Manajemen Pelayanan Umum di Indonesia Cetakan Keenam. Jakarta: Bumi Aksara

Osborne, David. \& Ted Gaebler.1992. Reinventing Government: How the Entrepreneural Spirit Transforming the Public Sector. Jakarta: LPPM.

Parasuraman, A., Valerie A. Zethaml, \& Leonard Berry. 1994. .Reassesment of Expectations as A Comparison Standard in Measuring Service Quality: Implications for Futher Research.. Journal of Marketing. Vol. 58. January. hal.11-124.

Sampara, Lukman. 2000. Manajemen Kualitas Pelayanan. Jakarta: STIA-LAN Press

Sinambela, Poltak. 2006. Reformasi Pelayanan Publik, Teori, Kebijakan, dan Implementasi. Jakarta : Bumi Aksara
Yuyun dkk. 2006. Reformasi Terpadu Pelayanan Publik. Yogyakarta : Pemda DIY dan Kemitraan bagi Pembaruan Tata Pemerintahan di Indonesia

Warella Y. 1997. Administrasi Negara dan Kualitas Pelayanan Publik. Pidato Pengukuhan sebagai Guru Besar Ilmu Administrasi Negara. Semarang: Fakultas Ilmu Sosial dan Ilmu Politik, Universitas Diponegoro.

—_. 1995. Managemen Pelayanan Publik. Jakarta: Lembaga Administrasi Negara.

Keputusan Menteri Pendayagunaan Aparatur Negara Nomor 63/KEP/M.PAN/\&/2003 Tentang Pedoman Umum Penyelenggaraan Pelayanan Publik. Tidak Diterbitkan.

Keputusan Menteri Pendayagunaan Aparatur Nagara Nomor: 26: KEP/M.PAN/2/2004 Tentang Petunjuk Teknis Transparansi dan Akuntabilitas dalam Penyelenggaraan Pelayanan Publik 